\title{
A Comparison of Cefquinome Sulfate and Lincomycin Hydrochloride in the Treatment of Mastitis for Lactating Cows
}

Zhichun Gu, Xiaoqi Yuan, Zhenling Zeng ${ }^{1}$, Guoliang Jiang, Yingxian Tao, Xiaojun Jiao, Qiqing Xu, Wenhui Li, Efeng Guo, Shuzhen Zhou

10.18805/IJAR.BF-1454

\begin{abstract}
Background: The clinical treatment of dairy cow mastitis during the lactation period plays a significant role in dairy manufacture. In this work, 3 groups of lactating dairy cows with clinical mastitis were selected, for the first time, to explore the treatment effects using cefquinome sulfate and lincomycin hydrochloride through the udder injection.

Methods: The treatment effects with the udder injection of cefquinome sulfate and lincomycin hydrochloride were compared based on effective rate, cure rate, somatic cell reduction in the milk, decrease of cow body temperature and recovery of milk yield.

Result: Both cefquinome sulfate and lincomycin hydrochloride showed effective treatment on the dairy cow mastitis during the lactation period. The effective rate and the cure rate obtained with cefquinome sulfate were $88 \%$ and $80 \%$, which were higher than those treated with lincomycin hydrochloride (effective rate: $72 \%$ and cure rate: $64 \%$ ). Furthermore, the cefquinome sulfate test group seemed to display a better role in the reduction of somatic cells in milk, a decrease of cow body temperature and the recovery of milk yield.

Key words: Cefquinome sulfate, Clinical study, Cow mastitis, Lactating cow, Lincomycin hydrochloride.
\end{abstract}

\section{INTRODUCTION}

Milk has long become an essential nutrient in our daily diet, so the safety of milk quality directly affects human health. In fact, dairy cow mastitis is one of the most common diseases that seriously affect the quality of milk (Halasa et al., 2007; Dohare et al., 2021), directly resulting in huge losses to the development of the dairy industry. Cow mastitis can lead to the decline of milk cow's lactation function, which directly causes the rancidity of the milk and the excessive numbers of bacteria. According to reports, cow mastitis causes economic losses of up to 2 billion US dollars per year in the United States (Olde Riekerink et al., 2006) and 300 million New Zealand dollars per year in New Zealand (Denis et al., 2009), respectively. Specifically, the annual loss caused by recessive mastitis is at least 135 million yuan in our country (Li et al., 2014; Wang et al., 2019). Therefore, the treatment of cow mastitis is greatly important for the worldwide dairy industry.

Currently, the conventional treatment of domestic dairy cow mastitis is still based on the antibiotic treatment through the local udder infusion (Shpigel et al., 1997; Heikkilä et al., 2018). This approach is convenient to be operated with accurate medication, which has been widely used in the clinical treatment of cow mastitis (Zhang et al., 2016; Krömker and Leimbach, 2017). For cows with systemic symptoms of mastitis, they would also be injected with antibiotics in the whole body. Since clinical mastitis can be caused by multiple pathogenic bacteria, there are various types of antibiotics developed for clinical mastitis. Penicillin and $\beta$-lactam antibiotics are the most common types, including cloxacillin sodium, amoxycillin, cephalexin and ceftiofur hydrochloride and
Eastern Along Pharmaceutical, Foshan, Guangdong 528234, China. ${ }^{1}$ Huanan Agricultural University, Guangzhou 510000, China.

Corresponding Author: Shuzhen Zhou, Eastern Along Pharmaceutical, Foshan, Guangdong 528234, China.

Email: zhousz@easternalong.com

How to cite this article: Gu, Z., Yuan, X., Zeng, Z., Jiang, G., Tao, Y., Jiao, X., Xu, Q., Li, W., Guo, E. and Zhou, S. (2022). A Comparison of Cefquinome Sulfate and Lincomycin Hydrochloride in the Treatment of Mastitis for Lactating Cows. Indian Journal of Animal Research. DOI: 10.18805/IJAR.BF-1454.

Submitted: 11-10-2021 Accepted: 25-12-2021 Online: 21-01-2022

so on. So the further development of antibiotics would be significant for the treatment of cow mastitis (Ramasamy et al., 2021).

Cefquinome has attracted the great attention of veterinary clinicians due to its wide antibacterial spectrum, strong antibacterial activity and low tolerance (Shpigel et al., 1997; Ruegg, 2017; Yu et al., 2017). Particularly, cefquinome was reported to have a great antibacterial activity against both gram-positive and gram-negative bacteria (Swinkels et al., 2013). To date, it has been approved by the European Commission for Veterinary Medicines (CVMP) for the clinical treatment of respiratory bacterial infections in pigs, cattle and dairy cow mastitis. In order to further develop use clinical drugs suitable for cow mastitis, we would like to objectively evaluate therapeutic effects of cefquinome sulfate and lincomycin hydrochloride on clinical dairy cow mastitis. These results would provide a theoretical basis for the rational clinical development of effective drugs for the treatment of cow mastitis. 


\section{MATERIALS AND METHODS}

Drug and animal grouping

Cefquinome Sulfate Intramammary Infusion (LC, 20170502, $75 \mathrm{mg} / 8.0 \mathrm{~g}$ ) and Lincomycin Hydrochloride Breast Injection (LC, $20170501,0.35 \mathrm{~g} / 7.0 \mathrm{~g}$ ) produced by Eastern Along Pharmaceutical (Guangdong, China) were employed in the following clinical trials. The clinical trial was completed on a dairy farm at Qingyuan in Guangdong from June 2019 to June 2020. All the experimental dairy cows were diagnosed with typical clinical mastitis symptoms. Totally, 73 cows including 36 primiparous cows and 37 post-paratory cows with a weight of $425 \sim 510 \mathrm{~kg}$ were randomly divided into 3 groups. During the clinical trials, no antibacterial drugs were added to the dairy cow feed. In the control group (Group 1), 24 cows were continuously injected with physiological saline solution $(8.0 \mathrm{~mL}, 3$ times) over each $12 \mathrm{~h}$ via the milk tube injection. In the group treated with cefquinome Sulfate (Group 2), 25 cows were continuously injected with Cefquinome Sulfate ( $75 \mathrm{mg}, 3$ times) over each $12 \mathrm{~h}$ through the milk tube injection. In the group tested with lincomycin hydrochloride (Group 3), 24 cows were treated with the active drug lincomycin hydrochloride (0.35, 3 times) over each 12 $h$ through the milk tube injection.

\section{Drug efficacy determination}

Initially, cows with clinical mastitis were evidenced with symptoms of redness, swelling, heat, obvious breasts pain, a rise of body temperature and obvious milk changes. Specifically, the main observation of mastitis cow has the swelling, fever and hard milk area. The early milk juice sample was watery with small particles or flocs. After a few days of the disease, the milk gradually turned into a brownish-yellow liquid. Before the drug administration and on the 7 th day after the last drug administration, milk samples from each treated milk area were collected for somatic cell count (SCC) determination (SCC600, Beijing Tongde Venture Technology Co., Ltd.). During the milk sampling, the test milk sample $(10.0 \mathrm{~mL})$ was collected after the dumping of the first 3 squeezings. The efficacy of the drug was evaluated based on overall inspections on the 7 th day after the last drug administration. The efficacy of the drug was divided into three types including valid, basically valid, invalid treatments. Typically, the spirit and the appetite of sick cow were normal, the clots and the flocs in the milk disappeared, milk color and milk production returned to normal, redness, swelling, heat and pain in the milking area disappeared without any recurrence. In addition, the SCC of milk was $<500,000$ cells $/ \mathrm{mL}$. The cows with the above symptoms and experimental results were determined as a valid treatment. For the cows determined as basically valid cases, cow spirit and appetite, milk appearance and color, redness, swelling, heat and pain in the milking area were observed as the same as the valid case. But the milk SCC was obtained from 500,000 to 1 million cells $/ \mathrm{mL}$. For any case to be determined as invalid after the treatment, the clinical symptoms of sick cows, such as redness, swelling, heat and pain in the milking area, did not alleviate or disappear and even the condition of the disease continued or deteriorated (milk SCC $>1$ million cells $/ \mathrm{mL}$ ). The SPSS 13.0 software was employed to statistically analyze the significance of the difference in SCC determination. The chisquare $\left(\chi^{2}\right)$ test was used to compare inefficiency, cure rate and effective rate of each test group for significant differences.

\section{RESULTS AND DISCUSSION}

\section{Therapeutic results}

Based on the results observed on the 7th day after the last administration, various indicators and test results were combined to determine the efficacy of active components (cefquinome sulfate and lincomycin hydrochloride) and cure rate in three groups. In group 1, both effective rate and cure rate were $0 \%$ with the injection of saline solution. The effective rate and cure rate of the cefquinome sulfate in group 2 were $88 \%$ and $80 \%$, respectively. As for group 3 treated with lincomycin hydrochloride, the effective and the cure rates were $72 \%$ and $64 \%$. As compared with the test group, the difference in effective rate and cure rate between the groups was observed to be extremely significant $(P<0.01)$, indicating that the medication of the negative control group is ineffective for clinical mastitis. Both effective rate and cure rate derived from group 2 were much higher than those obtained from group 3. Therefore, cefquinome sulfate seems to be more effective for cow mastitis as compared with lincomycin hydrochloride.

\section{Milk SCC results}

Before the drug administration and on the 7 th day after the last drug administration, milk samples from each treatment area were collected for SCC measurements. The results were summarized in Table 1. The SCC between the cefquinome sulfate test group and the lincomycin hydrochloride control group was obtained to be significantly different $(P<0.05)$. As compared with the control group 1 , the SCC of groups 2 and 3 were significantly decreased $(P<0.05)$. Before the medication, the number of somatic milk

Table 1: Somatic cells count in the milk of infected cows before medication and on the $7^{\text {th }}$ day of last drug administration.

\begin{tabular}{lccr}
\hline Group & Cow numbers & $\begin{array}{c}\text { Before medication } \\
\text { (SCC, } 10000 \mathrm{cells} / \mathrm{mL})\end{array}$ & $\begin{array}{r}7^{\text {th }} \text { day of last medication } \\
(\mathrm{SCC}, 10000 \mathrm{cells} / \mathrm{mL})\end{array}$ \\
\hline 1 & 24 & $160.2 \pm 47.1$ & $145.3 \pm 51.6$ \\
2 & 25 & $159.4 \pm 48.5$ & $34.7 \pm 24.9$ \\
3 & 24 & $167.3 \pm 45.8$ & $85.6 \pm 41.2$ \\
\hline
\end{tabular}


cells in all infected milk areas was more than 1 million cells/ $\mathrm{mL}$. After the treatment with cefquinome sulfate and lincomycin hydrochloride, the SCC of all treated breast areas decreased significantly. Typically, the SCC in the cured breast area of the cefquinome sulfate breast injection from group 1 was less than $500,000 / \mathrm{mL}$ and the SCC in the treated breast area of the lincomycin hydrochloride breast injection in group 2 was ranged from 500,000 to 1 million cells $/ \mathrm{mL}$. These results proved that the cefquinome test group can significantly reduce the number of bovine somatic cells in clinical mastitis, as compared to the medication of lincomycin hydrochloride.

\section{Cow temperature change}

The body temperature of the infected dairy cow was recorded before the drug administration and on the $1^{\text {st }}, 3^{\text {rd }}$ and $5^{\text {th }}$ day after the last drug dose (Table 2). In group 1, the average cow body temperature was maintained at $40-41^{\circ} \mathrm{C}$, indicating the continuous infection of mastitis with an only injection of saline solution. As for the cefquinome sulfate group (group 2), the body temperature was the same as that observed in group $1\left(40-41^{\circ} \mathrm{C}\right)$. After the treatment using cefquinome sulfate, the average body temperature continuously dropped on the $1 \mathrm{st}$, 3rd and 5 th day after the last drug administration. Finally, the temperature dropped to normal body temperature scope $\left(38-39^{\circ} \mathrm{C}\right)$. These results confirmed that the cefquinome sulfate breast injection was effective to cure clinical mastitis. In group 3 , the average body temperature was $40.4^{\circ} \mathrm{C}$ before the administration of lincomycin hydrochloride. After drug injection, the temperature dropped to be lower than $40^{\circ} \mathrm{C}$, but it was observed to be $39.2^{\circ} \mathrm{C}$ on the $5^{\text {th }}$ of the last medication dose. These data inferred that lincomycin hydrochloride breast injection has a certain therapeutic and cooling effect on clinical mastitis. Moreover, the temperature decrease of group 2 seems to be slightly larger as compared with group 3 , concluding that cefquinome sulfate showed a better treatment effect than lincomycin hydrochloride.

\section{Milk yield}

As seen in Table 3, the average milk production of infected primipara cows in the negative control group 1 did not change much at various time points, ranging from 13.5-14.5 $\mathrm{kg} / \mathrm{day}$. Before the drug administration and on the $1^{\text {st }}$ day after the last administration, there was no significant difference in the average milk yield from groups 1-3 $(P>0.05)$. In group 2, with the udder injection of cefquinome sulfate, the average milk production before medication and 1 day after the last drug administration was $15-16 \mathrm{~kg} /$ day. On the 3rd and 5th day after the last medication, the average milk production recovered quickly, increasing up to $19.9 \mathrm{~kg} /$ day and $21.8 \mathrm{~kg} / \mathrm{day}$, respectively. These results evidenced that the cefquinome sulfate breast injection test group can quickly cure clinical mastitis to promote the recovery of milk production. In addition, the lincomycin hydrochloride group 3 also has a positive effect on the treatment of clinical mastitis. The average milk production on the $1^{\text {st }}$ day after the last medicine administration was about $15.3 \mathrm{~kg} /$ day.

Table 2: Body temperature of infected dairy cows before and after medication.

\begin{tabular}{|c|c|c|c|c|}
\hline \multirow[b]{2}{*}{ Group } & \multicolumn{3}{|c|}{ Cow body temperature $\left({ }^{\circ} \mathrm{C}\right)$} & \multirow[b]{2}{*}{$\begin{array}{r}\text { Day } 5 \text { of last } \\
\text { medication }\end{array}$} \\
\hline & Before medication & $\begin{array}{c}\text { Day } 1 \text { of last } \\
\text { medication }\end{array}$ & $\begin{array}{c}\text { Day } 3 \text { of last } \\
\text { medication }\end{array}$ & \\
\hline 1 & $40.3 \pm 0.06$ & $41 \pm 0.06$ & $40.7 \pm 0.04$ & $40.8 \pm 0.03$ \\
\hline 2 & $40.7 \pm 0.08$ & $39.2 \pm 0.41$ & $38.7 \pm 0.35$ & $38.8 \pm 0.30$ \\
\hline 3 & $40.4 \pm 0.04$ & $39.8 \pm 0.39$ & $39.2 \pm 0.50$ & $39.2 \pm 0.43$ \\
\hline
\end{tabular}

Table 3: Milk yield of infected primipara cows before and after treatment.

\begin{tabular}{|c|c|c|c|c|}
\hline \multirow[b]{2}{*}{$\begin{array}{l}\text { Group } \\
\text { (Cow numbers) }\end{array}$} & \multicolumn{3}{|c|}{ Milk production $(\mathrm{kg})$} & \multirow[b]{2}{*}{$\begin{array}{r}\text { Day } 5 \text { of last } \\
\text { medication }\end{array}$} \\
\hline & $\begin{array}{c}\text { Before } \\
\text { medication }\end{array}$ & $\begin{array}{l}\text { Day } 1 \text { of last } \\
\text { medication }\end{array}$ & $\begin{array}{c}\text { Day } 3 \text { of last } \\
\text { medication }\end{array}$ & \\
\hline $1(12)$ & $14.4 \pm 4.6$ & $14.7 \pm 2.9$ & $13.8 \pm 3.8$ & $13.7 \pm 3.5$ \\
\hline $2(12)$ & $15.3 \pm 5.1$ & $15.7 \pm 3.2$ & $19.9 \pm 3.4$ & $21.8 \pm 4.3$ \\
\hline $3(12)$ & $15.1 \pm 3.8$ & $15.3 \pm 4.9$ & $18.7 \pm 5.5$ & $20.9 \pm 4.1$ \\
\hline
\end{tabular}

Table 4. Milk yield of infected multipara cows before and after treatment.

\begin{tabular}{|c|c|c|c|c|}
\hline \multirow{2}{*}{$\begin{array}{l}\text { Group } \\
\text { (Cow numbers) }\end{array}$} & \multicolumn{3}{|c|}{ Milk production $(\mathrm{kg})$} & \multirow[b]{2}{*}{$\begin{array}{r}\text { Day } 5 \text { of last } \\
\text { medication }\end{array}$} \\
\hline & $\begin{array}{c}\text { Before } \\
\text { medication }\end{array}$ & $\begin{array}{c}\text { Day } 1 \text { of last } \\
\text { medication }\end{array}$ & $\begin{array}{c}\text { Day } 3 \text { of last } \\
\text { medication }\end{array}$ & \\
\hline $1(12)$ & $17.8 \pm 5.5$ & $16.8 \pm 6.7$ & $15.4 \pm 4.1$ & $15.2 \pm 5.8$ \\
\hline $2(13)$ & $17.1 \pm 4.7$ & $17.4 \pm 5.6$ & $20.2 \pm 3.6$ & $25.5 \pm 4.8$ \\
\hline $3(12)$ & $18.2 \pm 3.3$ & $17.8 \pm 4.6$ & $19.2 \pm 5.4$ & $22.3 \pm 4.3$ \\
\hline
\end{tabular}


The average milk production recovered quickly on the $3^{\text {rd }}$ and 5th day after the last medication, which was enhanced up to $18.7 \mathrm{~kg} /$ day and $20.9 \mathrm{~kg} /$ day, respectively. On the $3^{\text {rd }}$ and 5 th days after the last medication, there was a significant difference in the average milk yield between group 2 and the negative control group $1(\mathrm{P}<0.05)$. Based on the data between group 2 and group 3 , it is clear that cefquinome sulfate might have a better recovery effect on the initial milk yield.

The average milk production of infected multipara cows from three groups was summarized in Table 4 . In the negative control group 1, the average milk production range was about $15-18 \mathrm{~kg} /$ day with a gradual decline during the overall experimental period. With the udder injection of cefquinome sulfate, the milk yield amount was observed to be increased. Before the medication in group 2, the milk amount was $17.1 \mathrm{~kg} /$ day. On the $1^{\text {st }}$ day of the last drug dose, the average milk production value was observed to be 17.4 $\mathrm{kg} /$ day. A great enhancement of milk yield was observed up to 20.2 and $25.5 \mathrm{~kg} /$ day on the $3^{\text {rd }}$ and $5^{\text {th }}$ day after the last medicine administration, respectively. So the udder injection of cefquinome sulfate played a significant role in the milk recovery. As for test group 3 using lincomycin hydrochloride, a milk recovery was also observed. However, the enhancement degree was not that high as observed in group 2 with cefquinome sulfate. The initial milk product before mediation and on the 1st day of the last administration was about $17.8-18.2 \mathrm{~kg} /$ day. On the 5 th day of the last mediation, the milk amount was increased up to $22.3 \mathrm{~kg} /$ day, which was slightly lower as compared to that observed on the same experimental day in group 2. Therefore, both cefquinome sulfate and lincomycin hydrochloride can recover the milk yield. However, based on the data comparison between group 2 and group 3, lincomycin hydrochloride injection showed a slow milk recovery than cefquinome sulfate.

\section{CONCLUSION}

In this work, a comparison of cefquinome sulfate and lincomycin hydrochloride in the clinical treatment of dairy cow mastitis during the lactation period was reported. Our results confirmed that both cefquinome sulfate and lincomycin hydrochloride have effective treatment on the dairy cow mastitis during the lactation period, including reduction of somatic cells in milk, a decrease of cow body temperature and recovery of milk yield. Specifically, group 2 with the medication of cefquinome sulfate showed a better treatment effect. The effective rate and the cure rate of group 2 treated with cefquinome sulfate were $88 \%$ and $80 \%$, respectively, which were higher as compared to those in group 3 using lincomycin hydrochloride (effective rate: $72 \%$ and cure rate: $64 \%$ ). Moreover, cefquinome sulfate was also observed to play a better role in the reduction of somatic cells in milk, a decrease of cow body temperature and recovery of milk yield, as compared to the lincomycin hydrochloride test group. Therefore, we concluded that the udder injection of cefquinome sulfate would be useful for the clinical treatment of dairy cow mastitis during the lactation period.

\section{REFERENCES}

Denis, M., Wedlock, D.N., Lacy-Hulbert, S.J., Hillerton, J.E., Buddle, B.M. (2009). Vaccines against bovine mastitis in the new zealand context: What is the best way forward? New Zealand Veterinary Journal. 57: 132-140.

Dohare, A.K., Bangar, Y.C., Sharma, V.B., Verma, M.R. (2021). Modelling the effect of mastitis on milk yield in dairy cows using covariance structures fitted to repeated measures. Indian Journal of Animal Research. 55: 11-14.

Halasa, T., Huijps, K., Østerås, O., Hogeveen, H. (2007). Economic effects of bovine mastitis and mastitis management: $A$ review. Veterinary Quarterly. 29: 18-31.

Heikkilä, A.-M., Liski, E., Pyörälä, S., Taponen, S. (2018). Pathogenspecific production losses in bovine mastitis. Journal of Dairy Science. 101: 9493-9504.

Krömker, V., Leimbach, S. (2017). Mastitis treatment-reduction in antibiotic usage in dairy cows. Reproduction in Domestic Animals. 52: 21-29.

Li, Y.-F., Lin, W., Gu, X.-Y., Zeng, Z.-I., HE, L.-M., Fan, Y., Bo, Y., Shu, J.-h., Ding, H.-Z. (2014). Pharmacokinetics and residues of cefquinome in milk of lactating chinese dairy cows after intramammary administration. Journal of Integrative Agriculture. 13: 2750-2757.

Olde Riekerink, R.G., Barkema, H.W., Veenstra, S., Poole, D.E., Dingwell, R.T., Keefe, G.P. (2006). Prevalence of contagious mastitis pathogens in bulk tank milk in prince edward island. Canadian Veterinary Journal. 47: 567-572.

Ramasamy, T., Keerthana, S., Srinivasan, M.R., Chandrasekar, D., Porteen, K., Borthakur, A., Elamaran, A., Sriram, P. (2021). Molecular characterization of antibiotic resistance gene pattern of Staphylococcus aureus and Escherichia coli in mastitis affected dairy cows. Indian Journal of Animal Research. 55: 463-468.

Ruegg, P.L. (2017). A 100-year review: Mastitis detection, management and prevention. Journal of Dairy Science. 100: 10381-10397.

Shpigel, N.Y., Levin, D., Winkler, M., Saran, A., Ziv, G., Böttner, A. (1997). Efficacy of cefquinome for treatment of cows with mastitis experimentally induced using Escherichia coli. Journal of Dairy Science. 80: 318-323.

Swinkels, J.M., Cox, P., Schukken, Y.H., Lam, T.J. (2013). Efficacy of extended cefquinome treatment of clinical Staphylococcus aureus mastitis. Journal of Dairy Science. 96: 4983-4992.

Wang, L., Yang, F., Wei, X., Luo, Y., Guo, W., Zhou, X., Guo, Z. (2019). Prevalence and risk factors of subclinical mastitis in lactating cows in northwest china. Israel Journal of Veterinary Medicine. 74: 1.

Yu, Y., Fang, J.-T., Sun, J., Zheng, M., Zhang, Q., He, J.-S., Liao, X.-P., Liu, Y.-H. (2017). Efficacy of cefquinome against escherichia coli environmental mastitis assessed by pharmacokinetic and pharmacodynamic integration in lactating mouse model. Frontiers in Microbiology. 8: 1445.

Zhang, Z., Li, X., Yang, F., Luo, J., Wang, X., Liu, L., Li, H. (2016). Influences of season, parity, lactation, udder area, milk yield and clinical symptoms on intramammary infection in dairy cows. Journal of Dairy Science. 99: 6484-6493. 